\title{
Rancang Bangun Sistem Deteksi dan Informasi Lokasi Banjir Berbasis GSM
}

\author{
Lilian Efendi*, Wildian \\ Jurusan Fisika FMIPA UniversitasAndalas, Padang \\ Kampus Unand Limau Manis,Pauh Padang 25163 \\ *lilian.efendi01@gmail.com
}

\begin{abstract}
ABSTRAK
Alat pendeteksi banjir nirkabel berbasis GSM telah dirancang dengan menggunakan sensor ultrasonik HC-SR04. Alat ini bekerja berdasarkan tinggi permukaan air yang tergenang di jalan raya. Alat terdiri dari sensor ultrasonik yang diletakkan pada ketinggian $150 \mathrm{~cm}$ pada tiang jalan raya. Pada saatketinggian air mencapai $40 \mathrm{~cm}$, maka Arduino uno sebagai pengolah data dengan menggunakan bahasa $\mathrm{C}$ akan mengontrol program SIM800L untuk mengirim SMS sebanyak satu kali dengan rata-rata waktu pengiriman selama 12:06 s sampai ke nomor yang telah di daftarkan. Setelah SIM800L mengirim SMS yang berisi link lokasi banjir, SIM800L akan memberikan peringatan bahwasanya ada SMS masuk dengan cara me-misscall nomor yang telah didaftarkan sebanyak dua kali. Link tersebut dapat diakses dan kemudian dapat dilihat dimana lokasi banjir terjadi.

Kata kunci : GSM, sensor Ultrasonik HC-SR04, Arduino Uno, Bahasa C, SMS, link, misscall.
\end{abstract}

\section{ABSTRACT}

GSM-based wireless flood detection devices have been designed using HC-SR04 ultrasonic sensors. This tool works based on stagnant water level on the highway. The device consists of an ultrasonic sensor that is placed at a height of $150 \mathrm{~cm}$ on the highway pole. When the water level reaches $40 \mathrm{~cm}$, Arduino Uno as a data processor using C language will control the SIM800L program to send SMS contain flood location link, one time with an average delivery time of 12:06 s to the registered number. After that SIM800L will give a warning that there is an incoming SMS by misscalling the number that has been registered twice. The link can be accessed and then can be seen where the flood occurred.

Keywords: GSM, HC-SRO4 Ultrasonic sensor, Arduino Uno, C Language, SMS, link, misscall.

\section{PENDAHULUAN}

Menurut Badan Nasional Penanggulangan Banjir (2017) Kota Padang merupakan kota besar di Pulau Sumatera yang dikelilingi oleh perbukitan dan perbatasan dengan lautan serta memiliki kepadatan penduduk yang cukup tinggi. Dengan semakin padatnya penduduk di suatu kota, maka tingkat kebutuhan juga akan semakin tinggi, salah satunya di bidang transportasi. Kota Padang memiliki sistem transportasi yang dominan melalui jalur darat, khususnya prasarana transportasi di jalan raya. Transportasi yang sudah menjadi gaya hidup bagi sebagian besar masyarakat di Kota Padang, juga menjadi salah satu tanggungjawab pemeritah untuk mengoptimalkan palayanan di jalan raya, terhitung sejak tahun 2002 banjir di Kota Padang sudah terjadi sebanyak 249 kali .

Ketika banjir terjadi, banyak jalan yang tergenang air sehingga menghambat beberapa aktivitas sehari-hari. Oleh karena itu peneliti sebelumnya telah merancang alat pendeteksi dini banjir. Sulistyowati dkk.(2015) telah melakukan penelitian untuk memprediksi banjir dengan menggunakan sensor ultrasonik dan mikrokontroler dengan media komunikasi SMS Gate Way, yang mana sistem pendeteksi ini bekerja secara otomatis untuk mengetahui ketinggian (level) air sungai secara realtime. Saputra dan Wildian (2015) telah melakukan penelitian dengan merangkai sensor berbasis potensiometer putar dan menggunakan modulasi digital FSKmodulasi frekuensi. Hasil penelitian ini didapatkan jarak maksimum pengiriman data yang dapat ditempuh hanya sepuluh meter dan masih pada skala laboratorium. Yuzria (2017) telah melakukan penelitian menggunakan sensor ultrasonik dengan sistem telemetri nirkabel yang dapat menjangkau jarak hingga $1 \mathrm{~km}$, namun sistem ini dapat diaplikasikan apabila ditambahkan sebuah antena eksternal.

Berdasarkan hasil dari penelitian yang telah dilakukan sebelumnya, peneliti merancang alat pendeteksi banjir yang diletakkan di hulu sungai, sehingga hasil yang didapat hanya informasi banjir yang terjadi di dekat sungai. Oleh karena itu dilakukan penelitian pendeteksi banjir dengan meletakkan sensor pada tiang yang berada di jalan raya pada ketinggian $150 \mathrm{~cm}$, 
dimana pada saat air mencapai ketinggian $40 \mathrm{~cm}$, itu sudah dapat dikatakan berbahaya karena menurut berita Republika.co.id, Padang (2018), Pada tanggal 9 Sept 2018 ketinggian air ratarata mencapai $50 \mathrm{~cm}$, pada ketinggian tersebut air sudah memasuki mesin kendaraan yang dapat menyebabkan mogok.

Dampak dari banjir tersebut dapat diminimalisir dengan memberikan informasi lokasi banjir yang terjadi kepada pengguna jalan sebelum melewati jalan tersebut sehingga pengendara bisa mencari jalan pintas atau jalan alternatif untuk menghindari macet dan banjir.

\section{METODE}

\subsection{Perancangan Diagram Blok Sistem}

Perancangan diagram blok sistem pada penelitian ini dibuat berdasarkan logika berpikir dalam mencapai hasil akhir yang bertujuan untuk memberikan informasi banjir dengan cara mengirimkan SMS berupa link location dari bencana. Diagram blok sistem ditunjukkan pada Gambar 1.

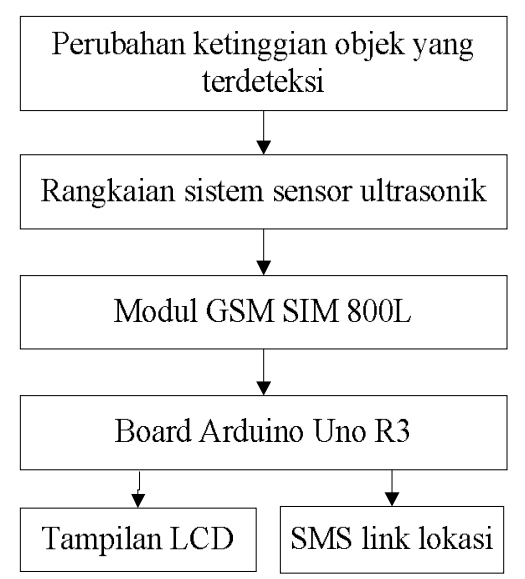

Gambar 1 Diagram blok sistem peringatan banjir

\subsection{Diagram Alir Perangkat Lunak Sistem}

Perancangan Program pada Arduino Uno menggunakan software dengan bahasa C. Untuk menjalankan program diawali dengan inisialisasi pin mikrokontroler. Program dibuat sesuai dengan port yang telah ditentukan. Port A0 sebagai port masukan dari sistem sensor, sedangkan untuk port keluaran menggunakan port digital sebagai keluaran berupa tampilan niai ketinggian permukaan air yang ditampilkan pada layar LCD dan link location dalam bentuk SMS pada smartphone. Sebelum melakukan pemrograman pada PC terlebih dahulu dibuat diagram alir perangkat lunak yang dapat dilihat pada Gambar 2 .

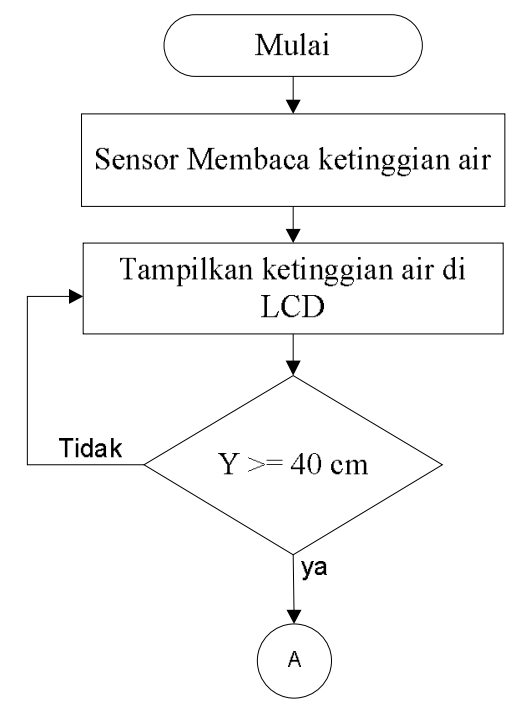




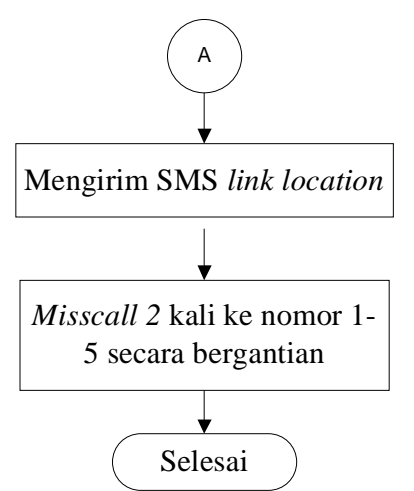

Gambar 2 Diagram alir program sistem pendeteksi banjir

\subsection{Rancangan Alat Secara Keseluruhan}

Rancangan alat terdiri dari beberapa alat dan komponen sebagai berikut:

1. Sensor ultrasonik, sebagai sensor pendeteksi ketinggian air.

2. Arduino UNO R3, sebagai board pendukung kerja mikrokontroler.

3. Modul SIM800L digunakan sebagai transceiver SMS dari arduino smartphone.

4. Modul GPS digunakan untuk menerima dan menentukan titik lokasi.

5. PCB berlubang, sebagai tempat rangkaian.

6. Kabel pelangi, untuk menghubungkan komponen.

7. Timah, untuk menghubungkan antar komponen dengan komponen ke PCB.

8. Pembatas tegangan

9. Box akrilik untuk kerangka alat.

10. LCD untuk menampilkan tinggi permukaan air.

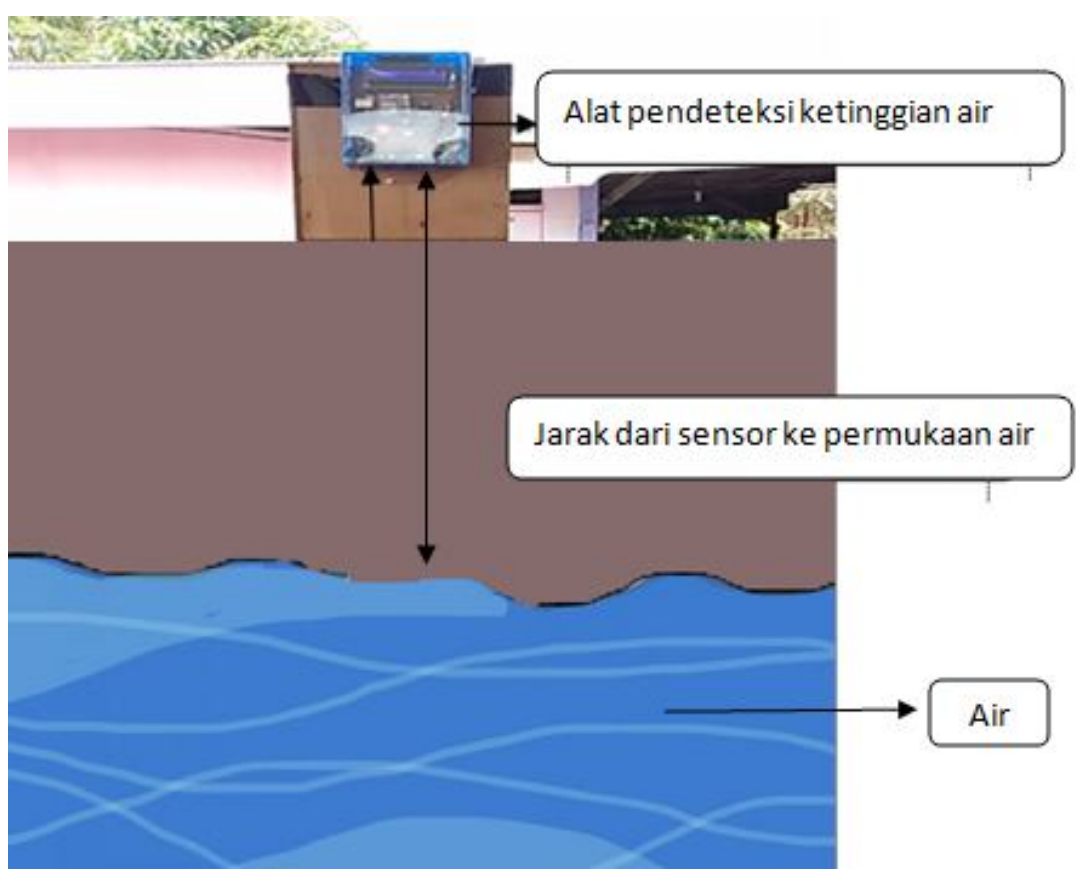

Gambar 3 Rancang alat pendeteksi banjir

Pengujian ini dilakukan pada satu titik lokasi dalam skala kecil, dimana alat ditempel pada box kayu, sedangkan objek yang akan dideteksi oleh sensor adalah air yang ada di dalam ember. ember berisi air yang berasal dari keran, jarak dari sensor ke dasar ember adalah $150 \mathrm{~cm}$, sehingga ketika air bertambah dan ketinggian air melebihi $40 \mathrm{~cm}$ atau nilai yang terbaca oleh sensor adalah $110 \mathrm{~cm}$, maka sensor ultrasonik akan mengirimkan informasi ke Arduino dan SIM800L akan mengirim SMS berupa link location yang dapat di akses oleh Android menggunakan aplikasi google maps ke nomor handphone yang telah didaftarkan sehingga pengguna dapat mengetahui lokasi terjadinya banjir. 


\section{HASIL DAN DISKUSI}

\subsection{Hasil Karakterisasi Sensor Ultrasonik HCSR-04}

Karakterisasi sensor ultrasonik HC-SR04 dilakukan untuk mengetahui kemampuan sensor dalam membaca tinggi permukaan air. Rangkaian arduino UNO R3 dengan sensor ultrasonik HC-SR04 dihubungkan dan upload program karakterisasi sensor ultrasonik ke arduino UNO R3 melalui software Arduino 1.6.6. pada komputer. Program karakterisasi sensor ultasonik HC-SR04 dapat dilihat pada Lampiran 1.

Sensor ultrasonik HC-SR04 diarahkan ke wadah yang berisi air dengan level muka air tertentu. Volume air dalam wadah ditambah secara bertahap sehingga didapatkan variasi level muka air. Data perbandingan ketinggian permukaan air diukur dengan meteran gulung, dan ketinggian permukan air yang terbaca oleh sensor dapat dilihat pada Tabel 1.

Tabel 1 Data perbandingan ketinggian air yang diukur menggunakan sensor dan meteran

\begin{tabular}{cc}
\multicolumn{2}{c}{ gulung } \\
\hline $\begin{array}{c}\text { Ketinggian air yang terbaca } \\
\text { oleh sensor ultrasonik }(\mathbf{c m})\end{array}$ & $\begin{array}{c}\text { Ketinggian air yang terukur } \\
\text { dengan meteran gulung }(\mathbf{c m})\end{array}$ \\
\hline 6 & 6 \\
7 & 7 \\
8 & 8 \\
9 & 9 \\
10 & 10 \\
11 & 11 \\
12 & 12 \\
13 & 13 \\
14 & 14 \\
15 & 15 \\
\hline
\end{tabular}

Berdasarkan Tabel 1 dapat dilihat bahwa hasil keluaran dari sensor ultrasonik HC-SR04 adalah nilai digital, sehingga sensor memiliki keakuratan yang tinggi. Karakterisasi sensor ultrasonik HC-SR04 ini dapat dilihat pada Gambar 4.

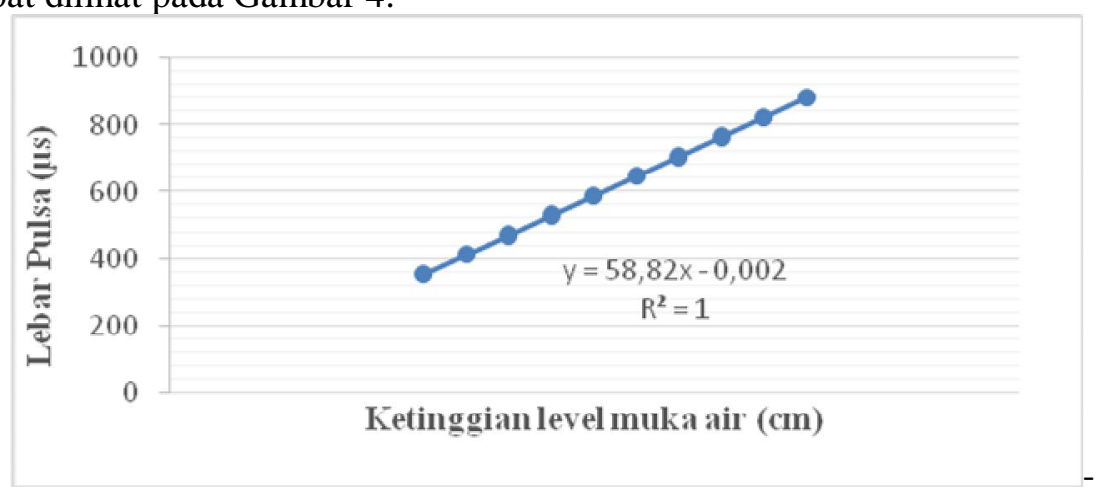

Gambar 4. Grafik lebar pulsa dan ketinggian permukaan air

Pada Gambar 4 dapat dilihat bahwa lebar pulsa sensor ultrasonik HC-SR04 berbanding lurus dengan ketinggian level muka air. Semakin tinggi level muka air, maka lebar pulsa akan semakin besar. Hal ini dibuktikan dengan derajat grafik korelasi linier yang cukup baik, yaitu $R^{2}=1$. Sensitivitas sensor ultrasonik HC-SR04 adalah $0,017 \mu \mathrm{s} / \mathrm{cm}$ dengan arti tiap kenaikan jarak sebesar $1 \mathrm{~cm}$ mengakibatkan kenaikan lebar pulsa sebesar $0,017 \mu \mathrm{s}$.

\subsection{Hasil Pengujian SIM800L}

Pengujian dilakukan dengan menghitung waktu respon Arduino sejak pesan dikirimkan hingga pesan diterima oleh pengguna. Pengujian waktu pengiriman SMS sampai SMS diterima dilakukan dengan jarak yang berbeda. Pengujian dilakukan dengan memvariasikan jarak antara pengirim dan penerima yaitu $3,2 \mathrm{~km}, 10 \mathrm{~km}, 11 \mathrm{~km}, 16 \mathrm{~km}$, dan $18 \mathrm{~km}$. Rata-rata waktu respon dari delapan kali percobaan dapat dilihat pada Tabel 2. 
Tabel 2 Variasi Jarak Terhadap Waktu Pengiriman SMS sampai SMS diterima

\begin{tabular}{cc}
\hline Jarak $(\mathbf{k m})$ & $\begin{array}{c}\text { Rata-rata WaktuPengiriman SMS } \\
\text { sampai SMS diterima (detik) }\end{array}$ \\
\hline 3,2 & $11: 46$ \\
10 & $12: 66$ \\
11 & $10: 82$ \\
16 & $12: 11$ \\
18 & $13: 09$ \\
\hline
\end{tabular}

Dari ke lima data yang didapatkan, terlihat jarak tidak mempengaruhi waktu pengiriman SMS sampai SMS diterima oleh pengguna.

\subsection{Hasil Uji SIM800L Call_Up}

Pengujian SIM800L call_up dilakukan untuk masing-masing nomor yang telah didaftar kan dan diatur pada program sebanyak dua kali call_up, hasil yang diperoleh dapat dilihat pada Tabel 3. Data yang diperoleh untuk pengujian SIM800L Call_Up bekerja dengan baik untuk masing-masing nomor dengan jarak yang berbeda, yaitu dapat me-misscall nomor handphone yang telah didaftarkan dengan cara bergantian, setelah me-misscall pertama nomor yang yang telah didaftarkan secara berurutan selama lebih kurang $12 \mathrm{~s}$ sampai lima nomor yang didaftarkan termisscall, kemudian kembali me-misscall nomor untuk kedua kali nya.

Tabel 3 Pemanggilan SIM800L pada masing-masing nomor

\begin{tabular}{ccc}
\hline No & Nomor Hp & Call_up \\
\hline 1 & 082391249977 & 2 kali \\
2 & 081261180779 & 2 kali \\
3 & 082170757559 & 2 kali \\
4 & 085212066289 & 2 kali \\
5 & 082388034136 & 2 kali \\
\hline
\end{tabular}

\subsection{Pengujian Rancang Alat Secara Keseluruhan}

Pengujian alat secara keseluruhan dilakukan dengan pengujian ketinggian air belum melebihi batas normal, dan ketika air melebihi batas normal. Hasil pengujian alat secara keseluruhan dapat dilihat pada Tabel 4.

Tabel 4 Pengujian rancang alat secara keseluruhan

\begin{tabular}{cccc}
\hline $\begin{array}{c}\text { Tinggi Permukaan } \\
\text { Air pada LCD }\end{array}$ & $\begin{array}{c}\text { Status yang } \\
\text { ditampilkan pada } \\
\text { LCD }\end{array}$ & $\begin{array}{c}\text { Send_SMS berupa } \\
\text { link location }\end{array}$ & Call_Up \\
\hline $35 \mathrm{~cm}$ & Tidak ada banjir & - & - \\
& SMS ke no 1 & Satu kali & Dua kali \\
& SMS ke no 2 & Satu kali & Satu kali \\
$45 \mathrm{~cm}$ & SMS ke no 3 & Satu kali & Dua kali \\
& SMS ke no 4 & Satu kali & Dua kali \\
& SMS ke no 5 & Satu kali & Satu kali \\
$45 \mathrm{~cm}$ & Masih banjir & - & - \\
\hline
\end{tabular}

Berdasarkan Tabel 4 menunjukkan bahwa setiap unit telah berfungsi dengan baik. Tinggi permukaan air telah dideteksi dengan baik oleh sensor ultrasonik HC-SR04 pada ketinggian $35 \mathrm{~cm}$ dan $45 \mathrm{~cm}$, data yang diperoleh untuk send_sms dapat dikatakan berhasil karena sesuai dengan yang tertulis pada program, untuk data call_up untuk no 2, diperoleh hasil bahwasanya SIM 800L dapat me-misscall nomor tersebut sebanyak satu kali, begitu juga call_up untuk no ke 5, berkemungkinan hal ini terjadi dikarenakan jaringan dari SIM800L atau nomor handphone pengguna yang kurang baik. 


\section{KESIMPULAN}

Berdasarkan data dan analisis serta pengujian hasil keseluruhan rancang bangun sistem deteksi dan informasi lokasi banjir berbasis GSM menggunakan sensor HCSR-04 dapat bekerja seperti yang telah direncanakan dan berjalan sesuai dengan yang diinginkan. Pembacaan ketinggian permukaan air yang ditampilkan pada layar LCD 16x2 dan sistem alarm (SMS dan call_up) diproses menggunakan Arduino Uno R3. Sistem peringatan banjir mampu mengirimkan informasi lokasi banjir menggunakan layanan SMS dan call_up.

\section{DAFTAR PUSTAKA}

Rossy, C.W., Utomo, W.H. dan Wallen, T., "Perancangan dan Implementasi Sistem Informasi Layanan Short Messaging Service (SMS)", Jurnal Informatika, Vol.2, No.2, Hal 156157, Universitas Kristen Satya Wacana, 2006

Saputra, S. Dan Wildian, "Rancang Bangun Sistem Telemetri Nirkabel untuk Peringatan Dini Banjir dengan Modulasi Digital FSK. Modulasi Freskuensi”, Jurnal Fisika Unand, Vol.4, No.1, Universitas Andalas, Padang, 2015

Sulistyowati,R., Sujono, H.A. dan Musthofa, A.K., "Sistem Pendeteksi Banjir Berbasis Sensor Ultrasonik dan Mikrokontroler dengan Media Komunikasi SMS Gate Way", Seminar Nasional Sains dan Teknologi Terapan, ISBN 978_602_98569_1_0, Fakultas Teknologi Informasi, ITATS, Surabaya, 2015

Yuzria, H.O., "Rancang Bangun Sistem Peringatan Dini Banjir menggunakan Metode Telemetri Nirkabel dengan Tranceiver nRf 24L01+", Tesis, PPs Unand, Padang, 2017

Badan Penanggulangan Bencana Daerah Kota Padang tahun 2017. 